It was stated that the operative-search characteristic of fraud committed by organized groups, in contrast to other domestic fraud, has its own peculiarities, which are expressed in criminological, forensic, vikimologicheskih and criminal-law signs, and knowledge of which in practical activity gives operatives the opportunity to maximize It is a short time to maximally effectively counteract this type of crime.

Key words: operative-search characteristics, fraud committed by organized groups, counteraction.

Колодяжний М. Г.

кандидат юридичних наук, старший науковий співробітник, завідувач відділу кримінологічних досліджень Науково-дослідного інституту вивчення проблем злочинності імені академіка В. В. Сташиса

Національної академї правових наук Украӥни (м. Харків, Україна)

\title{
СУСІДСЬКА ВАРТА В СИСТЕМІ ПРОФІЛАКТИКИ ЗЛОЧИННОСТІ ЗА КОРДОНОМ І В УКРАЇНІ
}

У статті досліджено перспективний для України напрям профілактики злочинності у вигляді сусідської варти. Вивчено зарубіжний досвід його реалізації у США, Великій Британії, країнах-членах ЄС. Виділено основні форми сусідської варти, переваги порівняно 3 іншими заходами спеціально-кримінологічного запобігання злочинності. Досліджено сучасний стан сусідської варти в нашій державі. Надано пропозиції щодо ії дальшого впровадження в Україні.

Ключові слова: сусідська варта, профілактика злочинності, стратегія «community policing», стратегія зменшення можливостей учинення злочинів.

Постановка проблеми. Відповідно до Стратегії національної безпеки України, затвердженої Указом Президента України від 26 травня 2015 року № 287/2015, одними з головних загроз національній безпеці нашої країни є інституційна слабкість, непрофесійність, структурна незбалансованість органів сектору безпеки, включаючи Національну поліцію України, поєднані з високим рівнем корупції за усією вертикаллю органів державного управління [1]. Недарма названі загрози не дають змоги приборкати злочинність в Україні, яка фактично має тенденцію до зростання. Офіційні статистичні показники правоохоронних органів є лише «цифровою ширмою», що штучно формує велику частку латентної злочинності. Це робиться, 3 одного боку, для прикриття непрофесіоналізму керівництва органів кримінальної юстиції, а з іншого - для зменшення страху громадян перед злочинністю, яка збільшується.

1 Примітка. Стаття підготовлена в межах розробки фундаментальної теми дослідження «Стратегія зменшення можливостей учинення злочинів: теорія і практика» відділу кримінологічних досліджень НДІ ВПЗ ім. акад. В. В. Сташиса НАПрН України.

(С) Колодяжний М. Г., 2019 
Безперечно, посилення криміногенності в державі на тлі «паперового зменшення» злочинності, що виходить із офіційних показників кримінальноправової статистики (487,1 тис. злочинів у 2018 р. проти 523,9 тис. злочинів у 2017 р. - зменшення на 7 \%), зумовлює затяжна соціально-економічна криза, через яку більшість українців перебуває за межею бідності. Указані процеси так чи інакше збільшують умовну психологічну прірву між суспільством і державою, що відсторонилася від реального вирішення соціальних проблем громадян, які небезпідставно менше довіряють правоохоронним органам й виявляють пасивність у партнерських відносинах з поліцією. Тому цілком логічно МВС України викликами у створенні безпечного середовища визнає недостатній рівень участі суспільства в механізмах запобігання злочинності й нерозуміння населенням своєї активної ролі в забезпеченні громадської безпеки [2].

3 огляду на висвітлені негативні обставини задля реальної, а не «штучно статистичної» стабілізації рівня злочинності в Україні, а також підвищення довіри громадян до правоохоронних органів виникає потреба в додатковому кримінологічному дослідженні тих напрямів профілактики злочинності, які сприятимуть посиленню активності громадян у партнерських відносинах із Національною поліцією як визначального суб'єкта в запобіганні найбільш поширеним злочинним проявам. Йдеться про сусідську варту (Neighborhood Watch), яка в багатьох країнах (США, Велика Британія, Канада, Австралія, деякі інші країни-члени СС) наразі є головним напрямом державно-приватного партнерства у сфері запобігання злочинності в межах стратегії «соmmunity policing» (громадська поліцейська діяльність) і стратегії зменшення можливостей учинення злочинів.

Аналіз останніх досліджень і публікацій. Профілактичні можливості програм сусідської варти досліджували здебільшого західні учені, такі як: Г. Баземор, Т. Беннетт, Е. Даріан-Сміт, Дж. Еврі, Г. Лейкок, К. Новак, Т. Озог, Д. Розенбаум, Б. Сміт, П. Стедженга, Б. Тернер, Н. Тіллі, М. Форст, Д. Хьорлі та інші. В Україні окремі аспекти цієї проблематики вивчали О. М. Бандурка, В. В. Голіна, В. І. Московець, С. Г. Поволоцька, В. О. Соболєв, О. Ю. Шостко, С. С. Шрамко, О. Н. Ярмиш тощо.

Формування цілей. Мета статті - з'ясування сутності та форм прояву програм сусідської варти за кордоном й надання на цій основі пропозицій щодо далышого впровадження вказаного напряму профілактики злочинності в Україні.

Виклад основного матеріалу. Програми сусідської варти (сусідського спостереження) наразі є одним 3 найпоширеніших форм профілактики злочинності у західних країнах. Антикриміногенний потенціал таких програм полягає в тому, що завдяки суспільній пильності, спостереженню мешканців житлових кварталів за майном один одного в потенційних злочинців зменшується можливість реалізувати злочинну мотивацію, спрямовану зазвичай на вчинення крадіжок, поєднаних 3 проникненням у житло, грабежів, розбоїв, угонів автотранспорту, хуліганств, актів вандалізму та інших злочинів і правопорушень. 
Уперше програма сусідської варти, що спочатку називалася «USAonWatch», почала реалізовуватись у США в 1972 р. за підтримки й часткового фінансування Національної асоціації шерифів за рахунок грантів Міністерства юстиції цієї країни [3]. 3 огляду на значний профілактичний потенціал цієї програми вона упроваджується й до сьогодні не лише в США, а й у багатьох державах світу, таких як Велика Британія, Канада, Австралія, ФРН, Нідерланди та інших європейських країнах. У США близько 20 \% родин мешкають у районах, де функціонують такі проекти, а третина 3 них самі беруть участь у цих програмах. Ключовим принципом сусідської варти є розширення неформального нагляду та своєчасного інформування поліції про вчинені правопорушення й злочини. Це сприяє збільшенню кількості арештів i, як наслідок, - скороченню рівня злочинності. Така практика також зменшує страх громадян перед злочинністю, підвищує безпеку в районі проживання [4, с. 17].

У США після терористичних атак, що відбулись у Нью-Йорку 11 вересня 2001 року, значення сусідської варти істотно зросло. Наразі учасники цих проектів не лише пильнують місцевість проживання, а й забезпечують готовність громад до стихійних лих (торнадо, цунамі, землетруси), формують належне реагування сусідів на різні надзвичайні ситуації, інформують громадськість про загрозу тероризму.

У Великій Британії програми сусідської варти, як і в США, є найвідомішим проектом запобігання злочинності, що було запроваджено в цій країні. На сьогодні в ньому бере участь понад $10 \mathrm{Mлн} \mathrm{осіб,} \mathrm{а} \mathrm{також}$ налічується понад 155 тис. осередків діяльності. Зазначена організація створена у Великій Британії ще в 1982 р., коли мешканці міста Моллінгтон вирішили об'єднати зусилля в боротьбі 3 квартирними крадіжками. Здійснюючи тісне співробітництво 3 поліцією, місцеві мешканці організували спостереження за майном своїх сусідів. Після запровадження цієї профілактичної програми відбулось суттєве скорочення квартирних крадіжок і навіть інших вуличних злочинів. До 1987 р. у Великій Британії вже існувало понад 42 тис. первинних осередків програми «Сусідська варта». За словами Т. Мей, перед тим міністра внутрішніх справ, а зараз чинного Прем'єр-міністра цієї країни, скоротити злочинність з 19 млн злочинів у 1995 р. до 6,6 млн злочинів у 2015 р. вдалося саме завдяки запровадженню комплексної правоохоронної стратегії, гідне місце в якій посідають програми сусідської варти [5, с. 3].

Особливістю цього проекту $є$ те, що його учасники не беруть безпосередньої участі в затриманні злочинців та їхньому переслідуванні. Вони допомагають опосередковано, повідомляючи місцевим органам поліції про підозрілих осіб чи факт розпочатого (вчиненого) злочину. Тому й неофіційний девіз програми звучить так: «Громадяни, які намагаються брати правосуддя у свої руки, не допомагають, а лише заважають боротьбі зі злочинністю».

Програма сусідської варти характеризується тим, що ії організація та запровадження починається із загальних зборів мешканщів багатоквартирного 
будинку, житлового мікрорайону. Учасники проекту висувають кандидатуру, яка здійснюватиме координування між громадянами й поліцією. Для цього в штатному розкладі поліцейських відділів передбачено посаду офіцера із зв'язками 3 громадськістю, який навчає населення навичкам правомірної поведінки; консультує з питань особистої безпеки й віктимологічної профілактики; роз'яснює положення процесуального законодавства; видає учасникам сусідської варти плакати, наклейки із зображенням логотипу місцевої програми, що розміщують при в'їзді до певного населеного пункту, на стінах магазинів і державних установ, будинках громадян тощо.

Роль самих учасників сусідської варти полягає в постійній зацікавленості подіями, що відбуваються в районі проживання, та проблемами ії мешканців; спостереженні за будинками і майном сусідів; створенні враження постійної присутності мешканців, які поїхали у відпустку чи відрядження (прибирання газет, пошти, розміщення власного автомобіля на сусідській стоянці, увімкнення світла на дворі у вечірній час); повідомленні поліції за телефоном чи на особистому прийомі про підозрілих осіб [6, с. 257-268].

Західні країни намагаються модернізовувати традиційні напрями профілактики злочинності на кшталт сусідської варти, запроваджуючи нові технології. Зокрема, у США організація «Neighborhood Watch» (Сусідська варта) у 2017 р. розробила спеціальне програмне забезпечення під назвою «Платформа скорочення злочинності в громадах» (Platform to Reduce Crime in Communities). Це додаток до смартфону або планшету «Black Box Digital Witness» (Цифровий свідок), який можна безкоштовно завантажити в мережі Інтернет. Його суть полягає в тому, що користувач має можливість оперативно спрямувати своєму шерифові за місцем проживання записане на мобільний телефон відео, на якому зафіксована злочинна поведінка певних осіб. Також користувачі можуть обмінюватись у соціальних мережах інформацією про підозрілих осіб. Поліція і спецслужби США покладають на цей додаток великі надії з огляду на протидію тероризму, а також негуманному поводженню з тваринами [7]. Очевидно, що цей підхід сприяє оперативності реагування поліцейських на вчинені злочини, підвищенню якості їх розслідування.

Одним 3 різновидів сусідської варти є програми запобігання угонам автомобілів «Спостерігаю за Вашим автомобілем» (Watch Your Car). Суть програми в тому, що власник автомобіля, який не користується ним у нічні години доби, дає згоду поліції для участі в ній, заповнює спеціальну анкету. Йому видають два стікери, що наклеюють на переднє й заднє вітрове скло автомобіля. Стікери мають світловідбиваючі елементи, що дає змогу бачити їх у темряві. 3 огляду на те, що більшість викрадень автомобілів відбувається саме вночі, поліцейські мають право зупиняти автомобілі з подібними наклейками з 1.00 год. до 5.00 год., перевіряючи наявність у водія відповідних документів на право експлуатації таким автотранспортним засобом. Тобто пильність патрульних поліцейських і свідомих громадян у такий спосіб значно обмежує можливості для автовикрадачів у реалізації̈інього злочинного умислу. Наразі вказана програма реалізується в багатьох штатах США [8]. 
У деяких містах США реалізуються місцеві програми профілактики злочинності. Наприклад, у м. Кенмор (штат Вашингтон) існує доволі успішна практика щодо повідомлення громадянами про будь-які дії третіх осіб, що мають ознаки неправомірної поведінки. Зокрема, у цьому місті департамент поліції запровадив програму «Блокуюча варта» (Block Watch Program). Вона полягає, з одного боку, у зменшенні віктимізації ії учасників, а з іншого, - певного зникнення страху громадян перед злочинністю. Особи, які виявили бажання брати участь у цій програмі, мають дотримуватися певних правил безпеки, щоб не стати жертвою злочину: установлення сигналізації, освітлення будинку, запорів на всіх дверях помешкання, здійснення озеленення прибудинкової території тощо. Це є заходами просторової профілактики злочинів. Додатково такі особи мають щомісяця брати участь у спільних зборах, на яких сусіди та патрульний поліцейський обговорюють актуальні для житлового кварталу події, обмінюються інформацією про вчинені злочини й випадки антисоціальної поведінки [9].

Подібні програми «Блокуюча варта» функціонують у багатьох містах США і Великої Британії. Практика показує, що там, де вони запроваджуються, рівень загальнокримінальної злочинності значно зменшується. Зокрема, в англійському місті Бірмінгем був високий рівень крадіжок, поєднаних 3 проникненням у житло. Через деякий час після старту проекту «Block Watch Program» у дванадцяти з п'ятнадцяти районів цього міста таких крадіжок майже не спостерігалось. У місті Лейквуд (США, штат Колорадо) вказана програма дала змогу скоротити крадіжки зі зламом аж на 77 \%, а в місті Сайпресс (США, штат Каліфорнія) - на 52 \% [10].

3 огляду на високу ефективність програм «Блокуюча варта» у профілактищі злочинам їх використовують не лише для охорони правопорядку в громадських місцях, захисту майна громадян, а й адаптують до сфери бізнесу та діяльності фермерських господарств. Для цього розробляють подібні програми «Ділова варта» (Business Watch) й «Фермерська варта» (Farm Watch).

Зауважимо, що в західних країнах діяльність щодо сусідської варти та інших напрямів профілактики злочинів не $є$ формальною, широко висвітлюючись у ЗМІ. Органи кримінальної юстиції витрачають значні кошти на популяризацію новацій у сфері громадської безпеки. Для цього здійснюються соціологічні дослідження із застосуванням сучасних методик вивчення громадської думки, ставлення населення до поліції та основних напрямів ії роботи. Цей вектор діяльності поліції у США, Великій Британії, ФРН та інших розвинених європейських країнах реалізується в кращих традиціях «public relations» (зв'язків з громадськістю). Так звані PR-технології, охоплюючи й правоохоронну сферу, передбачають наявність у кожному управлінні поліції співробітників, відповідальних за інформування місцевої громади про злочинність, їі рівень, результати розслідування резонансних злочинів.

Вдалим прикладом застосування PR-технологій поліцією США є пес Макграфф. Це видуманий у 1980 р. Національною радою запобігання злочинності США антропоморфний (людиноподібний) образ поліцейського собаки породи бладхаунд. Спочатку Макграфф задумувався як спосіб 
поліпшення кримінологічної поінформованості американських дітей і підлітків про злочинність. Наразі він використовується для популяризації різних форм профілактики злочинів і небезпечної поведінки: сусідська варта, просторова профілактика, дотримання правил дорожнього руху тощо. До 25-річчя Макграффа, що відбулось у 2007 р., у США була оголошена загальнодержавна кампанія протидії крадіжкам, яка мала також заходи сусідської варти [11].

Щодо України, то практика реалізації програм «Сусідська варта» існує лише на рівні пілотних проектів. Вони більш-менш активно реалізуються із середини 2017 року. Першим містом, де програма «Сусідська варта» була впроваджена, стала Вінниця. Згодом до неї приєдналися Харків, Полтава, Хмельницький, Рівне, Чернівці, Луцьк. Очевидно, що такий досвід має поширюватися на інші обласні й районні центри України, не обмежуючись лише об'єднаннями співвласників багатоквартирних будинків (ОСББ). Учасниками таких програм профілактики злочинності мають бути й мешканці багатоповерхових будинків комунальної власності, приватних домоволодінь. На сьогодні передчасно говорити про результативність подібних програм профілактики злочинності в Україні.

Для дальшого впровадження окресленого напряму профілактики злочинності в Україні, що зарекомендував себе позитивно в десятках західних країн уже протягом майже півстоліття, можна висловити низку пропозицій. Вони зводяться до такого:

а) популяризація в місцевих громадах програм сусідської варти в спосіб: нагляду за сусідським майном, особливо у вихідні й святкові дні, період відпусток; обміну телефонами як між мешканцями будинків, так і 3 дільничним інспектором поліції; контролі входу й виходу з під'їздів будинків сторонніх осіб; повідомлення поліції про підозрілу та незаконну поведінку сусідів і сторонніх осіб (прояви сімейного насильства; винесення з будинку побутової техніки та великих валіз; продаж наркотичних речовин чи саморобних алкогольних напоӥв; ознаки вживання наркотиків i психотропних засобів (порожні коробки кадеїновмісних препаратів, використані шприци, порожні скляні пляшки для внутрішніх ін'єкцій); пошкодження комунального та приватного майна в під'їді чи на прибудинковій території тощо);

б) посилення взаємодії дільничних поліцейських 3 мешканцями, проведення на регулярній основі загальних будинкових, квартальних зборів, надання індивідуальних консультацій. 3 огляду на це потрібно поширити поліцейський проект «Візит» на всі населені пункти України. Суть проекту побудинковий і поквартальний обхід дільничними офіцерами поліції мешканців на території обслуговування для вивчення проблем 3 питань безпеки й отримання інформації про осіб, які вчиняють злочини чи правопорушення (досвід м. Харків);

в) схиляння громадян до добровільного надання поліції будь-яких відомостей, що містять ознаки злочину чи правопорушення; заборона самостійного вирішення чужого міжособистісного конфлікту в спосіб затримання злочинця, а тим більше вчинення інших самоправних дій, небезпечних для життя і здоров' я викривача злочинця; 
г) постійне інформування громадян про рівень криміногенності за місцем проживання, щоб не посилювати їхній страх перед злочинністю;

д) створення в державі спеціального фонду за рахунок як коштів державного бюджету, так і меценатів, з якого виплачуватиметься винагорода доброчесним інформаторам (цей досвід існує у США, Великій Британії, Канаді, Австралії та інших країнах, зокрема й СНД);

е) запровадження в Україні премії 3 умовною назвою: «Учасник сусідської варти року», «За мужність і небайдужість», «За прояв хоробрості та сміливості». Такі заходи мають популяризувати в нашій державі практику програм сусідської варти, залучаючи до участі в них максимальну кількість громадян;

є) розміщення на вході у двір багатоповерхового будинку, під'їзд, квартири або на огорожі приватного будинку таблички 3 написом «Цей будинок захищений сусідською вартою». Такі написи широко поширені за кордоном й інформують потенційних злочинців про очевидність їхніх злочинних дій через пильність місцевих мешканців, що значно зменшує настання злочинного результату без ризику для винного.

Ураховуючи, що програми сусідської варти є одним з багатьох проявів стратегіï «community policing» [12; 13], заслуговує також на увагу діяльність щодо налагодження партнерських відносин поліції зі школярством й студентством. 3 огляду на це потребує розширення практика впровадження програм профілактики злочинності на кшталт «Шкільний офіцер поліції». Перший досвід реалізації різноманітних заходів у межах програм «Сусідська варта» й «Шкільний офіцер поліції» показує, що майбутнє профілактики злочинності в Україні саме за подібними вузькопрофільними проектами. Вони є більш ефективні за розмиті й громіздкі комплексні державні, обласні та міські програми запобігання й протидії злочинності, що приймались у нашій країні раніше, більшість заходів яких реалізовувалася 3 ознаками нецільового використання бюджетних коштів.

Висновки. 3 огляду на викладене констатуємо:

1) програми сусідської варти є однією з центральних складових сучасної системи профілактики злочинності в багатьох західних країнах;

2) переваги сусідської варти порівняно 3 іншими напрямами профілактики злочинності полягають у скороченні рівня місцевої злочинності; економічності через здійснення частини ії заходів громадянами на добровільній і безоплатній основі; посиленні в громадян відчуття безпеки; зменшенні страху перед злочинністю; активізації зацікавленості мешканців у вирішенні проблем місцевої громади; налагодженні партнерських стосунків місцевого населення 3 поліцією 3 одночасним посиленням соціально-обслуговуючої функції; підвищенні авторитету правоохоронних органів у державі загалом;

3) ефективність сусідської варти залежить від багатьох обставин, як-от: iї популяризація з боку правоохоронних органів; фінансування заходів 3 боку держави, великого бізнесу, окремих громадян; розуміння громадянським суспільством власної ролі у забезпеченні правопорядку; 
4) в Україні сусідська варта лише розпочинає запроваджуватись. Для тї успішного функціонування необхідно вжити комплекс організаційноуправлінських, інформаційних й технічних заходів.

\section{Використані джерела:}

1. Про рішення Ради національної безпеки і оборони України від 26 травня 2015 року «Про Стратегію національної безпеки України»: Указ Президента України від 26.05.2015 № 287/2015. URL : http://zakon.rada.gov.ua /laws/show/287/2015 (дата звернення: 03.01.2019).

2. Стратегія розвитку органів системи Міністерства внутрішніх справ України до 2020 року. Київ: МВС України, 2017. 15 с.

3. Neighborhood Watch. URL: https://www.nnw.org/ (дата звернення: 03.01.2019).

4. Взаимодействие милиции и населения: $\mathrm{K}$ итогам харьковского эксперимента. Харьков: Нац. ун-т внутр. дел, 2003. 288 с.

5. Modern Crime Prevention Strategy. London: Home Office, 2016. 48 p.

6. Бандурка О. М., Соболєв В. О., Московець В. І. Партнерські взаємовідносини між населенням та міліцією: підручник. Харків: Вид-во Нац. ун-ту внутр. справ, 2003. $352 \mathrm{c}$.

7. National Neighborhood Watch Releases New Technology. URL: http://nnw.org/sites/default/files/documents/Safe City Press Release.pdf (дата звернення: 03.01.2019).

8. Watch Your Car Program. URL: http:/ / mdsp.maryland.gov/Organization/ Superintendent/Watch Your Car Program (дата звернення: 03.01.2019).

9. Block Watch Program. URL: http : / / www.kenmorewa.gov (дата звернення: 03.01.2019).

10. Crime Prevention Programs. URL: http://mrsc.org/Home/ExploreTopics/Public-Safety/Law-Enforcement (дата звернення: 03.01.2019).

11. The National Crime Prevention Council. URL: http://www.ncpc.org/about (дата звернення: 01.11.2018).

12. Колодяжний М. Г. Сучасний зарубіжний досвід громадського впливу на злочинність: монографія; за ред. В. В. Голіни. Харків: Право, 2017. 252 с.

13. Громадськість у запобіганні і протидії злочинності: вітчизняний та міжнародний досвід: монографія / В. В. Голіна, М. Г. Колодяжний, С. С. Шрамко та ін.; за заг. ред. В. В. Голіни, М. Г. Колодяжного. Харків: Право, 2017. 284 с.

Стаття надіӥшла до редколегї 22.01.2019

Колодяжный М. Г., кандидат юридических наук, старший научный сотрудник, заведующий отделом криминологических исследований Научноисследовательского института изучения проблем преступности имени академика В. В. Сташиса Национальной академии правовых наук Украины (г. Харьков, Украина)

\section{Украине}

Соседский дозор в системе профилактики преступности за границей и в

В статье исследовано перспективное для Украины направление профилактики преступности в виде соседского дозора. Изучен зарубежный опыт его реализации в США, Великобритании, странах-членах ЕС. Выделены основные формы соседского дозора, преимущества по сравнению с иными мерами 
специально-криминологического предупреждения преступности. Исследовано современное состояние соседского дозора в нашем государстве. Разработаны предложения по его дальнейшему внедрению в Украине.

Ключевые слова: соседский дозор, профилактика преступности, стратегия «community policing», стратегия уменышения возможностей совершения преступлений.

\section{Kolodiazhnyi M. Neighboring Guard in the Crime Prevention System Abroad and in Ukraine}

In the article, on the basis of familiarization with the special literature of western criminologists, analytical reports and policy documents in the field of combating crime investigated one of the most common and most effective lines of crime prevention in the form of neighborhood guards. It is relatively new to law enforcement in Ukraine. This article lists circumstances that indicate the relevance of the study of this issue.

The purpose of the article is to find out the nature and forms of manifestation of the programs of the neighboring guard abroad and to elaborate on this basis proposals for the further implementation of this direction of crime prevention in Ukraine.

It is noted that the neighboring guard is closely connected with such crime prevention strategies as "community policing" and a strategy to reduce the possibilities of committing crimes.

The essence of the neighboring guard, subjects of implementation of its various measures, main forms of its manifestation are described. The foreign experience of crime prevention through neighboring guards is based on analysis made in such developed western countries as the United States, Great Britain, Germany and other EU member states.

It is specified that the neighboring guard is particularly effective in preventing theft, combined with penetration into housing, robbery, vehicle theft, hooliganism, acts of vandalism and other street crimes and offenses.

The benefits of neighboring guards are listed in comparison with other directions of special-criminological crime prevention. Rated the status of implementation of a neighboring guard in Ukraine, which takes place only at the level of pilot projects in some cities.

Conclusions indicate that the neighboring guard is essential to the crime prevention system abroad. It requires further study on the subject of its implementation in the practice of law enforcement agencies of our country.

Key words: neighboring guard, crime prevention, strategy of «community policing», strategy of reducing the possibilities of committing crimes.

УДК 343.9.024:339.9 (477)

Краснов О. В. начальник оперативно-розиукового відділу ОРУ СХРУ Державної прикордонної служби України (м. Суми, Україна)

\section{ПРОТИДІЯ ОРГАНІЗОВАНІЙ ЗЛОЧИННОСТІ ОРГАНАМИ ДЕРЖАВНОЇ ПРИКОРДОННОЇ СЛУЖБИ УКРАЇНИ}

У статті розглянуто основні особливості сучасної організованої злочинності як явища транснаціонального характеру глобального масштабу, яке суперечить інтересам сталого розвитку людства в цілому. Констатується, що вчинення 